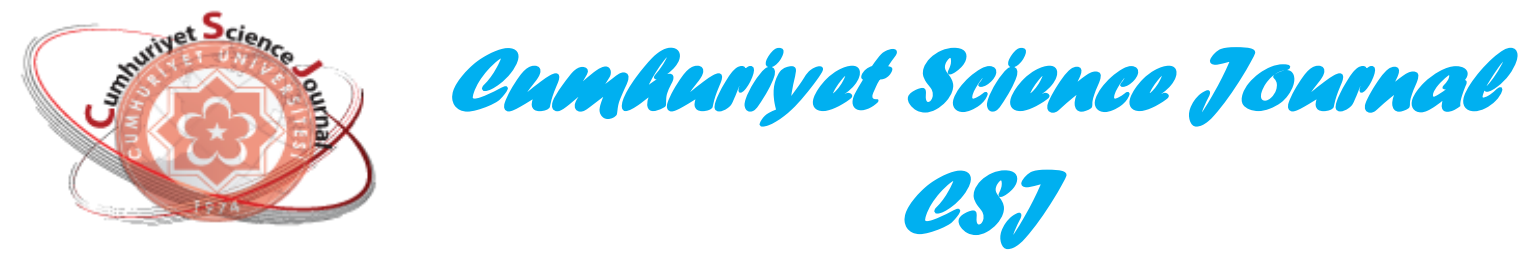

\title{
Effects of Cerium, Iron and Copper Incorporation on the Structural Properties and Activities of Ti-Pillared Bentonites
}

\author{
Funda TURGUT BASOGLU \\ Gazi University, Engineering Faculty, Chemical Engineering Department, Ankara, TURKEY
}

Received: 13.10.2017; Accepted: 27.04.2018

http://dx.doi.org/10.17776/csj.343221

\begin{abstract}
Ti-pillared bentonite (Ti-PB) using bentonite from the Middle Anatolia region (Hançl11) was synthesized. Iron or copper was impregnated to Ti-PB from the solution and subsequent cerium incorporation was done by wet impregnation. The hydrothermal syntheses were carried out with a $\mathrm{Cu} /(\mathrm{Cu}+\mathrm{Ti})$ ratios of 0.1 and 0.2. The anatase phase of titanium dioxide was found for all of the samples. The Ti-PB calcined at $500{ }^{\circ} \mathrm{C}$ gave a basal spacing value of $4.41 \mathrm{~nm}$, a specific BET surface area of $348 \mathrm{~m}^{2} \mathrm{~g}^{-1}$, and a micropore volume of $0.093 \mathrm{~cm}^{3} \mathrm{~g}^{-1}$. While the post incorporation of copper and iron caused decrease in the micropore properties, the hydrothermally synthesized copper titanium samples reflected the similar behavior with Ti-PB. Energy dispersive X-ray spectroscopy (EDS) analyses indicated that $\mathrm{TiO}_{2}$ content of all PBs was near $40 \mathrm{wt} \%$ and metal incorporation to Ti-PB was succesfully performed by the impregnation method. Ti-PB exhibited both the Lewis and Brønsted acidities. The copper impregnation resulted in an increase in the Lewis acidity. The hydrotermally synthesised copper containing sample and cerium-iron and cerium-copper impregnated samples yielded an increase in the Brønsted acidity. Approximately $90 \%$ phenol conversion at $30^{\circ} \mathrm{C}$ in an hour was achived with the cerium and iron containing sample and the completion of photocatalytic oxidation was reached at 2 hours. An increase of temperature rised the conversion of phenol, and the iron containing sample resulted in approximately $100 \%$ conversion at an hour at $50{ }^{\circ} \mathrm{C}$. Hydroquinone, benzoquinone and catechol and formic, malic, fumaric acids were observed as the reaction intermediates. The leaching of metals was observed at low values and the stability of iron was found six times higher than the copper.
\end{abstract}

Keywords: Ti-pillared bentonite, structural properties, surface acidity, photocatalytic wet peroxide oxidation.

\section{Seryum, Demir ve Bakır Emdirmenin, Ti-Sütunlu Bentonitlerin Yapısal Özellikleri ve Aktiviteleri Üzerine Etkileri}

\footnotetext{
Özet: Orta Anadolu yöresi (Hançıll) bentoniti kullanılarak, Ti-sütunlu bentonit (Ti-SB) sentezlenmiştir. TiSB'e demir ya da bakır, çözeltiden emdirilmiş ve devamında seryum, sslak emdirmeyle demirli ve bakırlı TiSB'e ilave edilmiştir. Bakırlı titanyumlu sütunlu bentonitler, $\mathrm{Cu} /(\mathrm{Cu}+\mathrm{Ti}) 0,1$ ve 0,2 oranlarında hidrotermal olarak sentezlenmiştir. Bütün numunelerde titanyum dioksit, anataz fazda görülmüştür. $500{ }^{\circ} \mathrm{C}$ de kalsine edilmiş Ti-SB için $4.41 \mathrm{~nm}$ bazal boşluk değeri, $348 \mathrm{~m}^{2} \mathrm{~g}^{-1}$ spesifik BET yüzey alanı, $0.093 \mathrm{~cm}^{3} \mathrm{~g}^{-1}$ mikrogözenek hacim değeri elde edilmiştir. Demir ve bakırın sonradan ilave edilmesi, elde edilen örneklerin mikrogözenek özelliklerinde azalmaya sebep olurken, hidrotermal yöntemle sentezlenen bakır titanyumlu örnekler, Ti-SB ile benzer davranış sergilemiş̧lerdir. Enerji dağılımlı X-ışını spektroskopisi (EDS) analizi, bütün örneklerin $\mathrm{TiO}_{2}$ içeriğinin ağırlıkça yaklaşık \% 40 civarında olduğunu ve Ti-SB'e metal emdirmenin başarılı bir şekilde gerçekleştiğini göstermiştir. Ti-SB örneklerinde hem Lewis hem de Brønsted asitliği gözlenmiş̧tir. Bakır emdirme, Lewis asitlikte artışa neden olmuştur. Hidrotermal olarak sentezlenmiş bakır içeren örneklerde, seryum demir ve seryum bakırlı örneklerde Bronsted asitliğinin arttığı gözlenmiştir. Seryum ve demir içeren örnekle gerçekleştirilen reaksiyon çalışmalarında yaklaşık $\% 90$ fenol dönüşümü, $30^{\circ} \mathrm{C}$ de 1 saat içinde elde edilmiş ve fotokatalitik oksidasyonun tamamlanması 2 saatde gerçekleşmiştir. Sicaklığın artması, fenol dönüşümünü artırmış ve demir içeren örnekle, $50{ }^{\circ} \mathrm{C}$ de 1 saat içinde yaklaşık $\% 100$ dönüşüm elde edilmiştir. Hidrokinon, benzokinon, katekol ve formic, malik, fumarik asitler reaksiyon ara ürünleri olarak gözlenmiştir. Düşük değerlerde metal salınımı ve demirin bakıra göre 6 kat daha fazla kararlılık gösterdiği gözlenmiştir.
}

Anahtar Kelimeler: Ti-sütunlu bentonit, yapısal özellikler, yüzey asitliği, fotokatalitik sslak peroksit oksidasyonu 


\section{INTRODUCTION}

Pillared inter-layered clays (PILCs) have unique properties and structures, which are formed by intercalation of metal polycations into the interlayer space of smectite clays. Calcination at moderate temperatures after intercalation transforms the polycations into stable oxihydroxide phases named pillars, the solids obtained thus being called pillared clays [1-3] PILCs which have thermal stability and high acidic character have been used in several catalytic reactions [4-6]. Pillaring by using polyoxycations of titanium gives a considerably larger interlayer space $[7,8]$. Although the presence of titanium in the structure gives photocatalytic property, the mixed metal incorporation by creating synergy makes improvement in the thermal strength in the pillar agent and catalytic properties [8-14]. While the hydrothermal metal incorporation results in less or no crystal deformation, the post synthesis gives especially the micropore pluging with the high achievable metal site in the PBs [10, 13,14].

Phenol is applied in various industrial processes such as refineries, petrochemical, pharmaceutical, coal and plastic industries as raw materials. Phenol and its derivative formed during the reaction are resistant to biodegradation and toxic even at low concentrations to living organisms. Treatment of phenolic wastewater by using processes like advanced oxidation (AOP), membrane processes, adsorption, and anaerobic/aerobic biological processes have been applied [15]. Catalytic wet peroxide oxidation (CWPO) which is one of the most effective, environmentally friendly and economical advanced oxidation process has been focused on. In CWPO, phenols are converted to stable inorganic compounds such as water, carbon dioxide and salts due to the electrophilic attack of the hydroxyl radical $\left(\mathrm{HO}^{*}\right)$, i.e. phenols undergo mineralization. CWPO over heteregeneous catalysts has been previously studied using transition metals and their complexes such as Fe, $\mathrm{Cu}$ and $\mathrm{Mn}$ and other metals such as $\mathrm{Si}, \mathrm{Al}$ and $\mathrm{Ti}$ based catalysts [16-23]. In these studies, metals have been typically used either in their pure oxide forms or their oxide forms on a micro/mesoporous support such as ZSM-5, Y5, SBA-15, pillared clay or activated carbon. Titanium based catalysts were used in photocatalytic oxidation of phenol in cooperation with UV-light to irradiate the reaction medium [24-29]. In some studies a cerium oxide as oxygen promoter in photocatalytic degredation of phenol was applied [29,30].

The aluminum-copper-iron, zirconium-cerium, manganese-copper on aluminum and ironaluminum containing PILC structures employed in the phenol oxidation exhibited good activity [16-18,31-39]. A limited number of studies involving titanium pillared structures have been reported in the literature $[10,40]$. In such applications, it was observed that the pore structure and the surface acidity had important effects on the conversion. PILCs containing iron oxide pillars (Fe-PILCs) known as promising heterogeneous Fenton catalysts have been used for the degredation of organic pollutants in wastewaters, combining a good catalytic activity with high stability against iron leaching [41-44]. In those studies, the hydroxyl radical was a very powerful oxidant and generated by Fenton reaction, that was the reaction of $\mathrm{Fe}^{3+}$ with $\mathrm{H}_{2} \mathrm{O}_{2}$. The UV light irradiation improved the effectiveness of the Fenton reaction due to regeneration of the consumed $\mathrm{Fe}^{2+}$ ions and directed $\mathrm{H}_{2} \mathrm{O}_{2}$ photolysis.

In the current study, the effects of the synthesis conditions on the physicochemical and catalytic properties of different combinations of cerium, iron, copper impregnated titanium pillared bentonites and the hydrothermally synthesized copper titanium mixed pillared bentonites were analyzed using XRD, $\mathrm{N}_{2}$ adsorption and desorption, SEM, EDS and FTIR techniques. The activities of some catalysts in photocatalytic wet peroxide oxidation of phenol were investigated. 


\section{MATERIALS AND METHODS}

\subsection{Synthesis of pillared layered bentonites (PBs)}

All of the chemicals, which were from Merck, Germany were of laboratory reagent grade. The bentonite from Hançı1ı (HB) was used as the host without any purification or pre-saturation. The physicochemical and mineralogical properties of the starting bentonite were previously reported by Turgut Basoglu and Balci's work [45]. The bentonite suspension with $0.2 \%$ mass percentages was swelled for 24 hours at room temperature and the synthesis of Ti-PB was carried out using some of advantages of the recipe suggested by Arfaoui et al. [46]. Titanium (IV) chloride $\left(\mathrm{TiCl}_{4}\right)$ as titanium source was used with the Ti/clay ratio of $10 \mathrm{mmol} / \mathrm{g}$. A $4.5 \mathrm{~cm}^{3}$ sample of $\mathrm{TiCl}_{4}$ was slowly added to $50 \mathrm{~cm}^{3}$ of a $0.2 \mathrm{M} \mathrm{HCl}$ solution under stirring to adjust the $\mathrm{H}^{+} /$Metal ratio to 0.24 . The pillaring solution was aged 15 hours at room temperature. The final solution was then added dropwise to the clay suspension, and 24 hours of dwell time was allowed under stirring for the ion exchange step. The solid particles were separated by means of centrifugation, and were then washed until the chloride was removed $\left(\mathrm{AgNO}_{3}\right.$ test was applied) [47]. The intercalated bentonites were dried for 5 days at room temperature, and then calcination was performed at either $300{ }^{\circ} \mathrm{C}$ or $500{ }^{\circ} \mathrm{C}$ for 3 hours. The hydrothermal synthesis of $\mathrm{Cu} 01 / \mathrm{Ti}-$ $\mathrm{PB}$ and $\mathrm{Cu} 02 / \mathrm{Ti}-\mathrm{PB}$ were carried out with a $\mathrm{Cu} /(\mathrm{Cu}+\mathrm{Ti})$ ratios of 0.1 and 0.2 and a $\mathrm{H} /(\mathrm{Cu}+\mathrm{Ti})$ ratio of 0.24 , maintaining metal/clay ratio again at $10 \mathrm{mmol} / \mathrm{g}$. The copper source was used as $\mathrm{Cu}\left(\mathrm{NO}_{3}\right) \cdot 3 \mathrm{H}_{2} \mathrm{O}$. The other synthesis parameters were kept the same as the Ti-PB synthesis and the solid samples were then calcined at $500{ }^{\circ} \mathrm{C}$ for 3 hours. The Fe@Ti-PB and $\mathrm{Cu} @$ Ti-PB samples were obtained by the impregnation from $100 \mathrm{~cm}^{3}$ of metal solution $\left(\mathrm{Fe}\left(\mathrm{NO}_{3}\right)_{3} .9 \mathrm{H}_{2} \mathrm{O}\right.$ or $\left.\mathrm{Cu}\left(\mathrm{NO}_{3}\right) .3 \mathrm{H}_{2} \mathrm{O}\right)$ to Ti-PB calcined at $300{ }^{\circ} \mathrm{C}$, with a $2 \mathrm{mmol} / \mathrm{gram}$ solid [48]. The suspension treated at $60{ }^{\circ} \mathrm{C}$ for 3 hours under stirring was centrifuged and the obtained solids were washed, dried at room temperature and then calcined at $500{ }^{\circ} \mathrm{C}$. The wet impregnation of cerium to 1 gram of these $\mathrm{PBs}$ was done using $3 \mathrm{~cm}^{3}$ of $0.02 \mathrm{M} \mathrm{Ce}\left(\mathrm{NO}_{3}\right)_{3} \cdot 6 \mathrm{H}_{2} \mathrm{O}$ solution $\left(\mathrm{Ce}_{\mathrm{w}}-\mathrm{Fe} @ \mathrm{Ti}-\mathrm{PB}, \mathrm{Ce}_{\mathrm{w}}-\mathrm{Cu} @ \mathrm{Ti}-\mathrm{PB}\right)$.

\subsection{Characterization studies}

The crystal structure of the bentonite and PB samples were evaluated by X-ray powder diffraction (XRD) patterns collected with a Rigaku Ultima IV diffractometer using a $\mathrm{Cu}-\mathrm{K} \alpha$ radiation source $(\lambda=0.15406 \mathrm{~nm})$ in the $2 \theta$ (Bragg angle) range of $1^{\circ}-70^{\circ}$ with a scan speed of $0.025 \mathrm{~s}^{-1}$ and a step size of 0.02 . The textural properties of the samples were studied by $\mathrm{N}_{2}$ adsorption/desorption measurements at $77 \mathrm{~K}$ within $\mathrm{P} / \mathrm{P}_{0}$ values of $10^{-7}-0.999$ in a Quantachrome Autosorp 1 C. Prior the physisorption, the samples were degassed at 300 ${ }^{\circ} \mathrm{C}$ for $6 \mathrm{~h}$ under high vacuum. The total pore volume $\left(\mathrm{V}_{\mathrm{T}}\right)$ as well as the micro- and mesopore volume $\left(\mathrm{V}_{\mu+\mathrm{m}}\right)$ were estimated from the desorption data at $\mathrm{P} / \mathrm{P}_{0}$ values of approximately 0.99 and 0.96, respectively. The specific BET (Brunauer, Emmett, Teller) ( $\mathrm{S}_{\mathrm{BET}}$ ) (within $\mathrm{P} / \mathrm{P}_{0}$ values of 0.05-0.30) and Langmuir $\left(\mathrm{S}_{\mathrm{L}}\right)$ (within $\mathrm{P} / \mathrm{P}_{0}$ values of 0.01-0.05) surface areas were calculated. Mesopore surface areas $\left(\mathrm{S}_{\mathrm{BJH}}\right)$, mesopore size distributions and mesopore volumes $\left(\mathrm{V}_{\mathrm{m}, \mathrm{BJH}}\right)$ were estimated by the BarrettJoyner-Halenda (BJH) method from desorption data within $\mathrm{P} / \mathrm{P}_{0}$ values of $0.96-0.35$. The micropore size distribution and micropore volume $\left(\mathrm{V}_{\mu}, \mathrm{HK}\right)$ were estimated by the Horvath and Kawazoe (HK) and the Dubinin-Astakhov (DA) methods. The t-plots were obtained using the de Boer thicknesses in order to adequate characterization of the micropore region. Total specific surface area and external surface area $\left(S_{\text {ext,t }}\right)$ values were estimated from the slope of the first and second linear segments of the t-plot, respectively. The micropore surface area $\left(S_{\mu, t}\right)$ was calculated as the difference between the specific BET surface area $\left(\mathrm{S}_{\mathrm{BET}}\right)$ and the external surface area $\left(S_{\text {ext, }, t}\right)$. Micropore volumes $\left(V_{\mu, t}\right)$ were determined from the intercept of the second linear segment of the t-plots [49,50]. The scanning electron microscopy (SEM) images of the gold-coated samples were recorded on a 
JEOL JSM 6060 at an accelerating voltage of 25 $\mathrm{kV}$. The near surface compositions of the HB and $\mathrm{PBs}$ were obtained using energy dispersive $\mathrm{X}$-ray spectroscopy (EDS) equipped in the scanning electron microscope. The metal compositions were measured over the selected area and reported in their oxide forms together with the loading success. The Fourier transform infrared spectroscopy (FTIR) spectra of the room-dried bentonite and all of the PBs were collected at $4 \mathrm{~cm}^{-1}$ resolution from 400 to 4000 $\mathrm{cm}^{-1}$ on a Bruker Vertex 70/70v equipped with a MCT detector. The samples were mixed with $\mathrm{KBr}$ at a mass ratio of $1 / 100$ for the measurement. The Brønsted and Lewis properties were studied by means of pyridine adsorption at room temperature and subsequent desorption from room temperature to $350^{\circ} \mathrm{C}$ by allowing approximately 30 minutes of dwell time at each desorption temperature. The pyridine adsorption was achieved by exposing the oven-dried samples to pyridine vapour under a vacuum of $0.013 \mathrm{~Pa}$ at room temperature for a week.

\subsection{Catalytic wet peroxide oxidation of phenol}

Ti-PB, Fe@Ti-PB, Cu@Ti-PB, Ce w $_{\mathrm{w}}$-Fe@Ti-PB, $\mathrm{Ce}_{\mathrm{w}}-\mathrm{Cu} @ \mathrm{Ti}-\mathrm{PB}$ were tested in phenol removal by photocatalytic wet peroxide oxidation of phenol. A represented synthetic wastewater with $50 \mathrm{mg} / \mathrm{L}$ phenol solution was used. Theoretically 14 mol of peroxide was necessary to completely oxidize $1 \mathrm{~mol}$ of phenol, the ratio of $\mathrm{H}_{2} \mathrm{O}_{2} /$ phenol $=16$ corresponding to 1.14 times of theoretical one was used. The oxidation was performed in a $250 \mathrm{~cm}^{3}$ reaction system equipped with a magnetic stirrer and under a Osram Germicidal Puritec HNS G5 UV lamp (length $=28.8 \mathrm{~cm}$, diameter $=1.6 \mathrm{~cm}, 8 \mathrm{~W}$, with wavelength of 254 $\mathrm{nm})$. The distance between the solution and UV source was kept constant at $15 \mathrm{~cm}$ in all of the experiments. The solid catalyst $(0.5 \mathrm{~g})$ was introduced into $100 \mathrm{~cm}^{3}$ of an aqueous phenol solution under continuous stirring. The reaction was carried out either at $30{ }^{\circ} \mathrm{C}$ or $50{ }^{\circ} \mathrm{C}$ and $\mathrm{pH}$ of reaction media was setted as either 3.7 or 5.0 by use of $0.1 \mathrm{M} \mathrm{NaOH}$ or $0.1 \mathrm{M} \mathrm{HNO}_{3}$ solution. The hydrogen peroxide solution $\left(8 \mathrm{~cm}^{3}\right)$ of 0.1 $\mathrm{M}$, was then added within 5 minutes. Around 1 $\mathrm{cm}^{3}$ of samples were drawn at certain time intervals and were filtered through a filter and analysed with a Shimadzu Prominence model High Performance Liquid Chromatography (HPLC). An Inertsil ODS-4 C18 column (4.6 $\mathrm{mm} \times 250 \mathrm{~mm}$ ) with a solvent mixture of water/methanol/acetic acid in the ratio 77/22/1 $(\mathrm{v} / \mathrm{v} / \mathrm{v})$ as the mobile phase for phenol and aromatic compounds and a Kromasil C18 column $(4.6 \mathrm{~mm} \times 150 \mathrm{~mm}, 5 \mu \mathrm{m})$ with water adjusted to $\mathrm{pH} 2.2$ using phosphoric acid solution as the mobile phase $(1 \mathrm{ml} / \mathrm{min})$ for carboxylic acids were used. The HPLC system was equipped with a diode array detector, and the absorbance measurements of both phenol and aromatic compounds (catechol, hydroquinone and benzoquinone) were obtained at 270, 276, 290 and $245 \mathrm{~nm}$ respectively [51]. For carboxylic acid species (formic, malic, fumaric, oxalic and acetic acids) expected as reaction intermediates, the measurements were performed at $210 \mathrm{~nm}$ [52]. Total organic carbon (TOC) of some final reaction mixtures was measured on a Shimadzu model VCPN carbon analyser (combustion method). The iron and copper analyses in the reaction mixture were also performed by atomic absorption spectrometry on a Philips PU9200X Atomic Spectrometer, to analyse the leaching possibility of the active metals at the final reaction mixture.

\section{RESULTS AND DISCUSSION}

\subsection{Characterization studies}

\subsubsection{X-ray powder diffraction patterns}

X-ray powder diffraction patterns of the bentonite and all of the PBs are given in Figure 1 and the basal spacing values of the samples are tabulated in Table 1. The bentonite gave high reflection intensity at the diffraction angle $(2 \theta)$ of $26.5^{\circ}$ corresponding to quartz and the reflections at $2 \theta$ of near $21^{\circ}$ and $28^{\circ}$ belonging to feldspate. One of the determining reflections of montmorillonite occurred near $26.6^{\circ}$. The reflection at $2 \theta$ value of $7.3^{\circ}$ which gave the basal spacing $\left(\mathrm{d}_{001}\right)$ value of $1.2 \mathrm{~nm}$, moved to lower value resulting a considerable increase in the basal spacing value $\left(\mathrm{d}_{001}=4.41 \mathrm{~nm}\right)$ with a decrease in its intensity by the pillaring with titanium. Although the pillaring of the bentonite generally caused no or small delamination, the bulky Ti-pillars could affect the shape of the 
pores so it revealed some degree of delamination. The partially disordered structure of oriented silicate layers by delamination could also weaken the basal reflection with a broadening as in consistent with the literature [40]. Whatever the method used, the metal incorporation to the Ti-PB reflected little increases in the Bragg angle values (Figure 1). The hydrothermally inserting of copper gave similar crystalline structure as observed with Ti$\mathrm{PB}$ at low copper concentration. Either copper or iron inserting to Ti-PB from solution gave no observable structural deformation. Cerium addition to each again resulted in no deformation due to its low concentration.

The titanium dioxide in the structure was mainly observed as in the anatase phase (reflections at approximately $25.3^{\circ}$ and $48.0^{\circ}[7,12,13]$ ) in Ti-PB structure and the phase was not changed with the further metal inserting. The intensities of these reflections in all of the samples were similar. The reflections of $\mathrm{CuO}\left(35.6^{\circ}, 38.9^{\circ}\right)$ [6,34], $\mathrm{Fe}_{2} \mathrm{O}_{3}$ $\left(33.0^{\circ}, 35.6^{\circ}, 54.0^{\circ}\right)$ and $\mathrm{CeO}_{2}\left(28.0^{\circ}, 47.5^{\circ}\right)$ were observed and reflections belonging to the metallic forms of all of the metals were not observed (Figure 1).
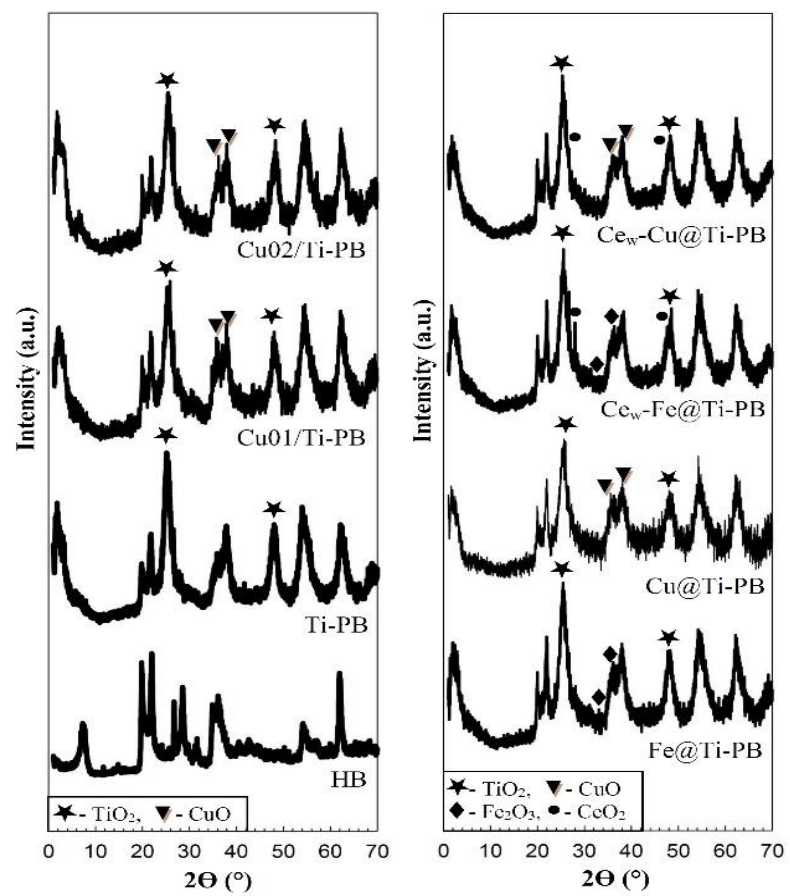

Figure 1. X-ray diffraction patterns of $\mathrm{HB}$ and pillared bentonites.

\subsubsection{Nitrogen isotherms}

adsorption/desorption

The nitrogen adsorption/desorption isotherms at liquid nitrogen temperature of all of the Ti-PBs are presented in Figure 2. The structural properties obtained from the interpretation of the isotherm data are tabulated in Table 1. The adsorption isotherms of all of the samples fitted the type IV isotherm which was characteristic for solids containing both micro and mesopores according to the International Union of Pure and Applied Chemistry (IUPAC) classification [50]. The H4type narrow hysteresis was observed within the relative pressure range of 0.40 to 0.99 due to the presence of mesopores. The observed similar hysterises trend for Ti-PB and the hydrothermally copper inserted Ti-PB were narrowed by the post metal inserting. Approximately $30 \%$ of total adsorption occurred at low relative pressures $\left(\mathrm{P} / \mathrm{P}_{0}\right.$ $<0.1)$ was related to the micropores. Ti-pillared bentonite calcined at $300{ }^{\circ} \mathrm{C}$ had $\mathrm{V}_{\mu, t}$ value of $0.112 \mathrm{~cm}^{3} \mathrm{~g}^{-1}$ and the hydrothermally synthesized copper titanium pillared bentonites showed similar micropore volume percentages. Up to $9-15 \%$ decrease in the micropore volume percentages occurred by the metal impregnation. The micropore volumes calculated from the HK method $\left(\mathrm{V}_{\mu, \mathrm{HK}}\right)$ were found as much higher than ones estimated from the $t$-method $\left(\mathrm{V}_{\mu, t}\right)$. The micro- and mesopore volumes $\left(\mathrm{V}_{\mu+\mathrm{m}}\right)$ of all of the samples reached to nearly $97 \%$ of the total pore volumes and those values were obtained as less than the calculated values determined by summation of the micropore volume $\left(\mathrm{V}_{\mu, t}\right)$ and the mesopore volume $\left(\mathrm{V}_{\mathrm{m}, \mathrm{BJH}}\right)$ for all of the pillared bentonites (Table 1). 


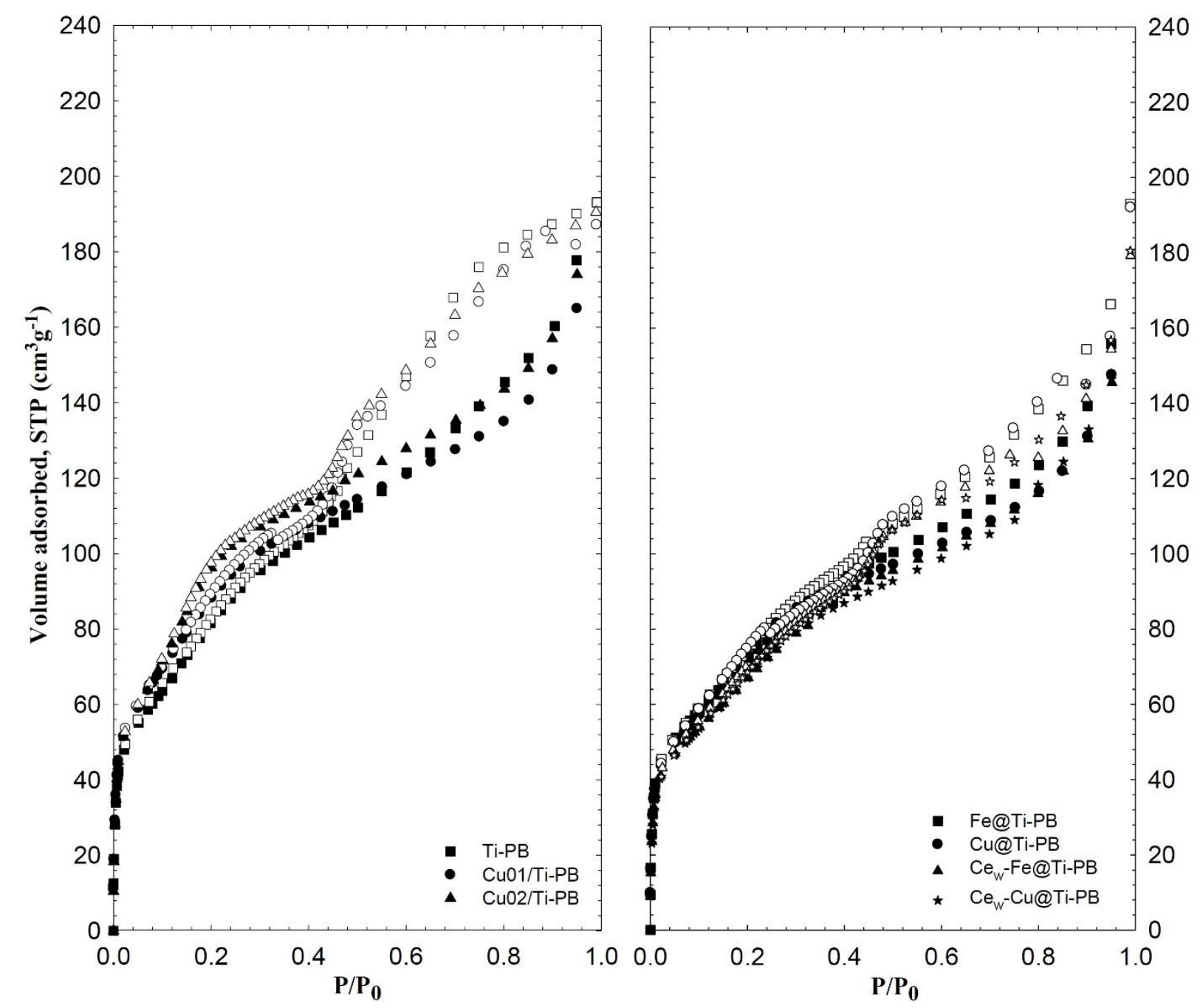

Figure 2. Nitrogen adsorption and desorption isotherms at $77 \mathrm{~K}$ for pillared bentonites (adsorption and desorption points are shown by filled and empty symbols, respectively). 
Table 1. Surface properties of titanium-pillared bentonites.

\begin{tabular}{|c|c|c|c|c|c|c|c|c|c|c|c|c|c|c|c|c|c|c|}
\hline \multirow{2}{*}{$\begin{array}{l}\text { Product code } \\
\text { (Active metal, } \\
\text { production type) }\end{array}$} & \multirow{2}{*}{$\begin{array}{l}\mathrm{d}_{001} \\
(\mathrm{~nm})\end{array}$} & \multicolumn{7}{|c|}{ Pore volumes $\left(\mathrm{cm}^{3} \mathrm{~g}^{-1}\right)$} & \multicolumn{6}{|c|}{ Specific surface area $\left(\mathrm{m}^{2} \mathrm{~g}^{-1}\right)$} & \multicolumn{4}{|c|}{ Aver. pore dimensions (nm) } \\
\hline & & $\mathrm{V}_{\mu, t}$ & $\mathrm{~V}_{\mu, \mathrm{HK}}$ & $\mathrm{V}_{\mu+m}$ & $\mathrm{~V}_{\mathrm{m}, \mathrm{BJH}}$ & $\mathrm{V}_{\mathrm{m}, \mathrm{BHHd}}$ & $V_{T}$ & $\% \mathrm{~V}_{\mu}$ & $\mathrm{S}_{\mathrm{BET}}$ & $\mathrm{S}_{\mathrm{L}}$ & $\mathrm{S}_{\text {ext,t }}$ & $\mathrm{S}_{\mu, \mathrm{t}}$ & $\mathrm{S}_{\mathrm{m}, \mathrm{BHHa}}$ & $\mathrm{S}_{\mathrm{m}, \mathrm{BHHd}}$ & $d_{H K}$ & $d_{D A}$ & $d_{B J H}$ & $\begin{array}{l}\text { Avg. pore } \\
\text { diameter }\end{array}$ \\
\hline Ti-PB300 & 4.46 & 0.112 & 0.165 & 0.277 & 0.147 & 0.184 & 0.283 & 40 & 372 & 300 & 121 & 251 & 78 & 145 & 0.43 & 1.84 & 3.71 & 3.05 \\
\hline Ti-PB500 & 4.41 & 0.093 & 0.154 & 0.270 & 0.153 & 0.175 & 0.277 & 34 & 348 & 279 & 133 & 215 & 81 & 124 & 0.43 & 1.82 & 3.66 & 3.19 \\
\hline $\mathrm{Cu} 01 / \mathrm{Ti}-\mathrm{PB} 500$ & 3.87 & 0.105 & 0.174 & 0.282 & 0.162 & 0.205 & 0.289 & 36 & 327 & 280 & 110 & 218 & 71 & 154 & 0.43 & 1.82 & 3.81 & 3.54 \\
\hline $\mathrm{Cu} 02 / \mathrm{Ti}-\mathrm{PB} 500$ & 4.05 & 0.108 & 0.184 & 0.290 & 0.156 & 0.184 & 0.295 & 37 & 361 & 283 & 120 & 241 & 69 & 135 & 0.43 & 1.84 & 3.72 & 3.27 \\
\hline Fe@Ti-PB500 & 4.22 & 0.087 & 0.153 & 0.266 & 0.211 & 0.211 & 0.299 & 29 & 265 & 242 & 106 & 160 & 95 & 109 & 0.43 & 1.80 & 3.73 & 4.50 \\
\hline Cu@Ti-PB500 & 4.13 & 0.090 & 0.148 & 0.256 & 0.189 & 0.218 & 0.297 & 30 & 279 & 235 & 92 & 187 & 62 & 117 & 0.43 & 1.76 & 3.73 & 4.25 \\
\hline $\mathrm{Ce}_{\mathrm{w}}-\mathrm{Fe} @ \mathrm{Ti}-\mathrm{PB} 500$ & 4.14 & 0.085 & 0.145 & 0.246 & 0.172 & 0.194 & 0.277 & 31 & 252 & 223 & 97 & 156 & 62 & 105 & 0.43 & 1.82 & 3.73 & 4.40 \\
\hline Ce $\mathrm{w}_{\mathrm{w}}-\mathrm{Cu} @ \mathrm{Ti}-\mathrm{PB} 500$ & 4.05 & 0.080 & 0.141 & 0.249 & 0.184 & 0.198 & 0.279 & 29 & 254 & 222 & 97 & 157 & 70 & 109 & 0.43 & 1.86 & 3.63 & 4.40 \\
\hline
\end{tabular}

All of the specific surface area values were found in an aggrement with the pore volume behavior. As in consistency with the surface improvement of bentonite by pillaring which was supported by the XRD pattern (Figure 1), the specific BET surface area of Ti-PB calcined at $300{ }^{\circ} \mathrm{C}$ was obtained as $372 \mathrm{~m}^{2} \mathrm{~g}^{-1}$, while that of bentonite has $57 \mathrm{~m}^{2} \mathrm{~g}^{-1}$ before pillaring with titanium. Increasing calcination temperature from $300{ }^{\circ} \mathrm{C}$ to $500{ }^{\circ} \mathrm{C}$ resulted in decrease in the specific BET surface area of Ti-PB to $348 \mathrm{~m}^{2} \mathrm{~g}^{-1}$ due to the removal of hydroxyl groups from the structure of pillared bentonite by temperature effect. The hydrothermal copper incorporation gave the similar specific surface area values, however impregnation of metals (copper or iron) caused decreases in the values. The Langmuir surface areas of samples were slightly less than the specific BET surface areas. Fe@Ti-PB and $\mathrm{Ce}_{\mathrm{w}}-\mathrm{Fe} @ \mathrm{Ti}-\mathrm{PB}$ gave close values of the external surface areas and the $\mathrm{BJH}$ desorption mesopore surface areas. The total specific surface area values calculated from the summation of the external surface area $\left(S_{\text {ext, }}\right)$ and the micropore surface area $\left(S_{\mu, t}\right)$ were found as close to the specific BET surface area for all of the Ti-pillared bentonites (Table 1).

The HK-micropore and the BJH-desorption mesopore size distribution curves of the samples are presented in Figure 3. The HK micropore size distribution for the Ti-pillared montmorillonite reflected generally bidispersed structure (centered at approximately $0.44 \mathrm{~nm} ; 0.94-1.64 \mathrm{~nm}$ ) in the micropore region (Table 1). The microporosity could be resulted both from the interpillar distance and voids within the titanium oxide phase. One narrow peak at approximately $3.63 \mathrm{~nm}-3.81 \mathrm{~nm}$ was obtained in the mesopore size distribution determined by the $\mathrm{BJH}$ method. The higher height of the maxima was observed for Ti-PB. Further metal impregnation to Ti-BP caused small decrease in them. The values obtained by subtracting the thickness of T-O-T layer from basal spacing $\left(\mathrm{d}_{001}\right)$ were found in an agreement with the BJH mesopore dimension. In order to see the delamination effect, the different pore geometry analysis by the Dubinin-Astakhov (DA) method was applied. The average micropore dimensions obtained by the DA method were almost found as four times higher than those obtained by the HK method. The height of the maxima for $\mathrm{Cu} @ \mathrm{Ti}-\mathrm{PB}$ in the DA micropore size distribution was observed high and more intense than others (Figure 3). 

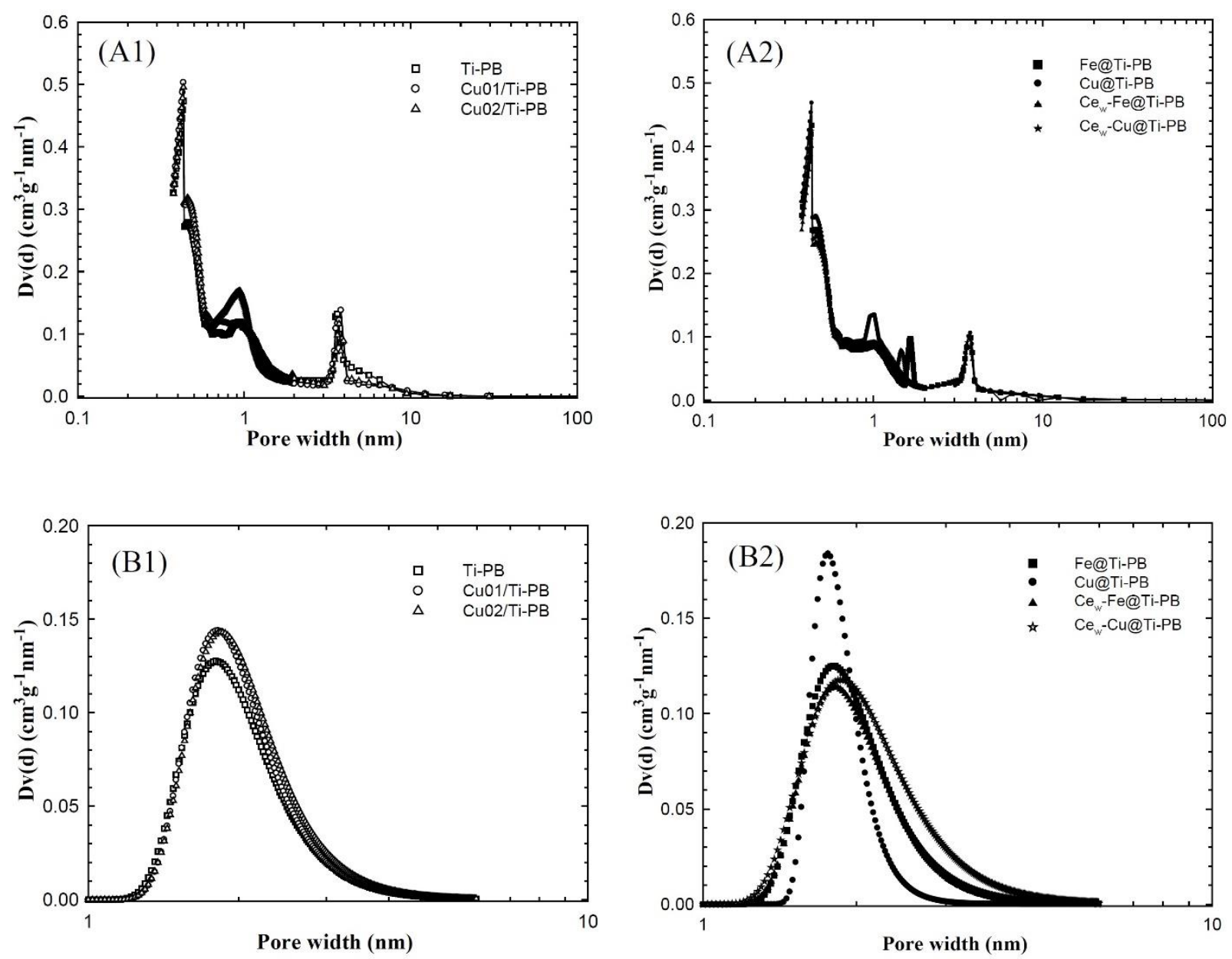

Figure 3. Pore size distribution curves of pillared bentonites obtained by using A1, A2) the HK and BJH methods $\quad$ B1, B2) the DA method.

\subsubsection{Scanning electron microscopy (SEM), and energy dispersive spectroscopy (EDS)}

The SEM micrographs of the Hanç1lı bentonite (HB) and some Ti-PB samples are shown in Figure 4 and the results from chemical analyses using EDS are listed in Table 2. The crystals of the Hanç1lı bentonite have cornflake-like appearance [6,7]. After pillaring, the fluffy popcorn-like structure was formed for both TiPB and the hydrothermally synthesized $\mathrm{Cu} 01 / \mathrm{Ti}-$ $\mathrm{PB}$, might be caused by a change in the surface charge of the particles [53]. The copper or iron impregnation resulted in flower-like pores. In consistent with the XRD patterns, the high $\mathrm{SiO}_{2} / \mathrm{Al}_{2} \mathrm{O}_{3}$ content of the bentonite indicated the presence of quartz and feldspar [6] (Table 2, Figure 1). The decreases in the amounts of exchangeable $\mathrm{Na}^{+}$and $\mathrm{Ca}^{+2}$ cations took place by pillaring with titanium polyoxycation (Table 2). The observed high $\mathrm{TiO}_{2}$ content was again consistent with the XRD results (Table 1, Figure 1), the $\mathrm{TiO}_{2} / \mathrm{SiO}_{2}$ mass ratios were reached to 1.0 and considerable decreases in the relative contents of silica and alumina were observed. The hydrothermally synthesized copper titanium mixed samples exhibited similar metal oxide contents with Ti-PB. The copper impregnation resulted in increases in loading success than the hydrotermal inserting. Due to little cerium amount (1\% loading), the EDS analysis did not give a cerium peak. The loading success of other metals were reached above $80 \%$ by the post impregnation. 

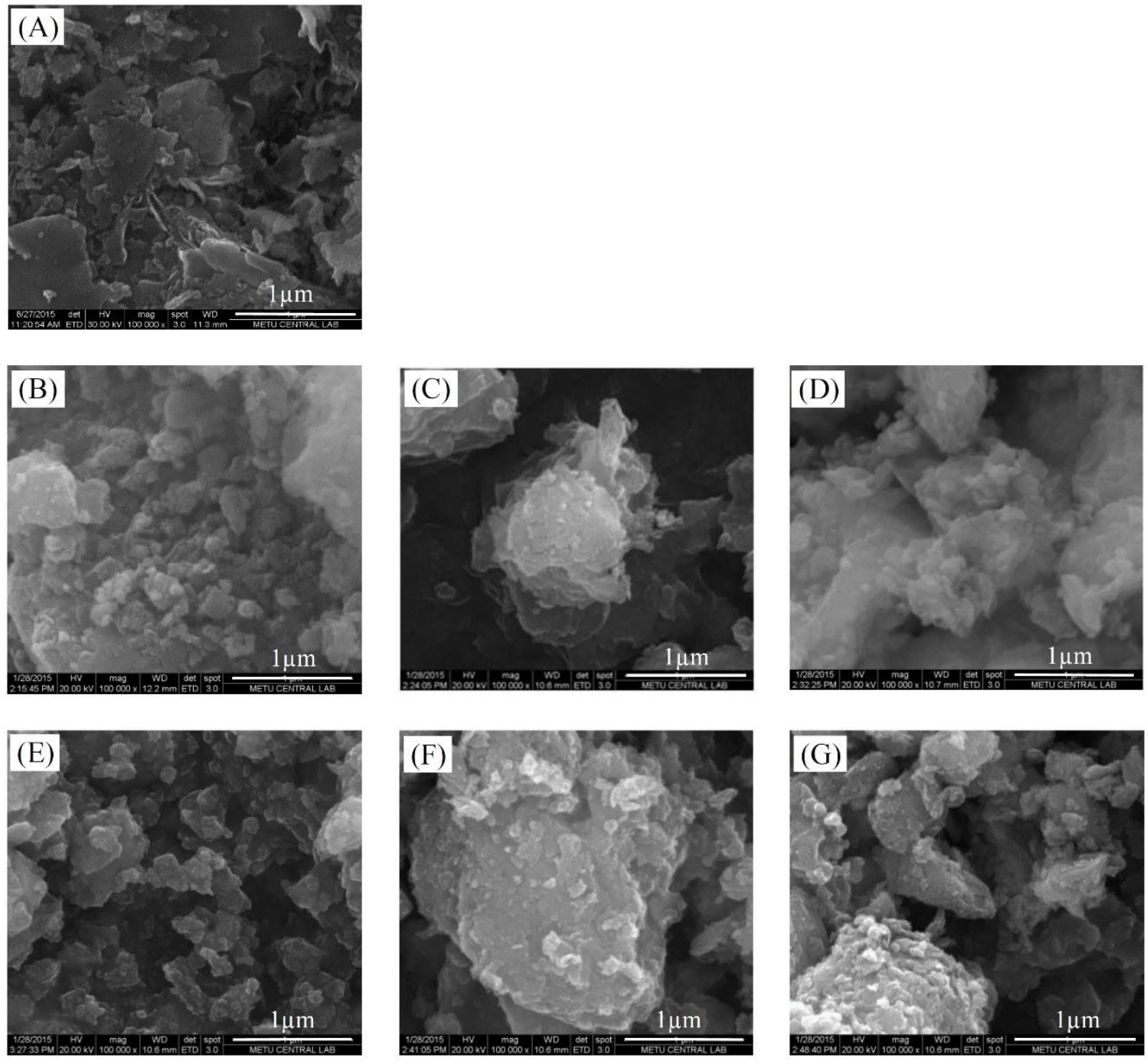

Figure 4. SEM micrographs of the bentonite and PB samples. A) HB B) Ti-PB C) Fe@ Ti-PB D) Cu@ Ti-PB E) Cu01/Ti-PB F) Ce - Fe@Ti-PB G) Ce $\mathrm{w}_{\mathrm{w}}-\mathrm{Cu} @ \mathrm{Ti}-\mathrm{PB}$.

Table 2. Chemical compositions of the HB, Ti-PBs estimated from EDS analyses.

\begin{tabular}{|c|c|c|c|c|c|c|c|c|c|c|c|c|c|c|c|c|c|c|c|c|}
\hline \multirow[t]{2}{*}{ Sample } & \multirow[b]{2}{*}{ 邑 } & \multirow[b]{2}{*}{ ర్ } & \multirow[b]{2}{*}{ ơ } & \multicolumn{3}{|c|}{$\%$ by mass } & \multirow[b]{2}{*}{$\begin{array}{l}\text { O } \\
\text { 坣 }\end{array}$} & \multirow[b]{2}{*}{ 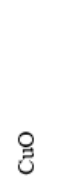 } & \multirow[b]{2}{*}{ ర్త్రీ } & \multirow[b]{2}{*}{ 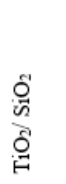 } & \multicolumn{4}{|c|}{ Molar ratios obtained } & \multicolumn{3}{|c|}{$\begin{array}{l}\text { Molar ratios } \\
\text { prepared }\end{array}$} & \multicolumn{3}{|c|}{ Loading success $\%$} \\
\hline & & & & 品 & 兽 & ర్ల & & & & & 苛 & 苞 & $\mathcal{U}_{j}^{E}$ & $\overrightarrow{2}$ & 苛 & 苞 & E & $\underset{⿱ 乛 龰}{\overrightarrow{8}}$ & 葛 & $\mathfrak{J}_{0}^{E}$ \\
\hline Bentonite & - & 75.14 & 18.09 & 2.97 & 1.07 & 0.47 & 2.26 & - & - & - & & & & & & & & & & \\
\hline Ti-PB & 42.51 & 42.54 & 11.46 & 2.08 & 1.41 & - & - & - & - & 1.00 & 0.03 & - & - & 0.75 & - & & & & & \\
\hline $\mathrm{Cu} 01 / \mathrm{Ti}-\mathrm{PB}$ & 42.19 & 42.34 & 11.46 & 1.52 & 1.39 & 0.24 & - & 0.86 & - & 1.00 & 0.03 & 0.02 & - & 0.75 & - & 0.11 & & & 18 & \\
\hline $\mathrm{Cu} 02 / \mathrm{Ti}-\mathrm{PB}$ & 41.73 & 41.87 & 11.92 & 1.41 & 1.40 & 0.15 & - & 1.52 & - & 1.00 & 0.03 & 0.04 & - & 0.75 & - & 0.25 & & & 16 & \\
\hline Fe@Ti-PB & 40.15 & 40.79 & 10.08 & 1.67 & 7.3 & - & - & - & - & 0.98 & 0.18 & - & - & 0.74 & 0.20 & & & 90 & & \\
\hline $\mathrm{Cu} @$ Ti-PB & 39.61 & 40.32 & 10.87 & 1.36 & 1.36 & - & - & 6.48 & - & 0.98 & 0.03 & 0.16 & - & 0.74 & - & 0.20 & & & 80 & \\
\hline $\mathrm{Ce}_{\mathrm{w}}-\mathrm{Fe} @ \mathrm{Ti}-\mathrm{PB}$ & 39.99 & 40.70 & 10.04 & 1.68 & 7.59 & - & - & - & - & 0.98 & 0.18 & - & - & 0.74 & 0.20 & & 0.01 & 90 & & $\mathrm{x}$ \\
\hline $\mathrm{Ce}_{\mathrm{w}}-\mathrm{Cu} @ \mathrm{Ti}-\mathrm{PB}$ & 39.51 & 40.28 & 10.88 & 1.76 & 1.41 & - & - & 6.17 & - & 0.98 & 0.04 & 0.16 & - & 0.74 & - & 0.20 & 0.01 & & 80 & $\mathrm{x}$ \\
\hline
\end{tabular}




\subsubsection{Fourier transform infrared (FTIR)} spectroscopy: surface functional groups and acidity

FTIR spectra of the room-dried and Ti-pillared bentonites are presented in Figure 5. The peaks corresponding to the $\mathrm{Si}-\mathrm{O}-\mathrm{Si}$ stretching, $\mathrm{Si}-\mathrm{O}$ bending and Al-O stretching vibrations were located at approximately $1038 \mathrm{~cm}^{-1}, 489 \mathrm{~cm}^{-1}$ and $524 \mathrm{~cm}^{-1}$ respectively in the FTIR spectra of the room-dried bentonite sample [9-11]. The stretching vibration of the structural hydroxyl groups at $3631 \mathrm{~cm}^{-1}$ and the water molecules present in the interlayer at $3446 \mathrm{~cm}^{-1}$ were observed [9,34]. The bending vibration of the water molecules resulting from surface hydroxyl groups was observed at $1638 \mathrm{~cm}^{-1}$. All of the bands corresponding to the bentonite structure were retained in all of the pillared samples indicating that the structure of the host mineral was unaffected by the pillaring and further metal incorporation. The intense peak at approximately $1038 \mathrm{~cm}^{-1}$ corresponding to the Si-O-Si stretching was shifted to $1044 \mathrm{~cm}^{-1}$. This change might be caused by a change in the symmetry of the surface $\mathrm{Si}-\mathrm{O}-\mathrm{Si}$ vibration, which was perhaps associated

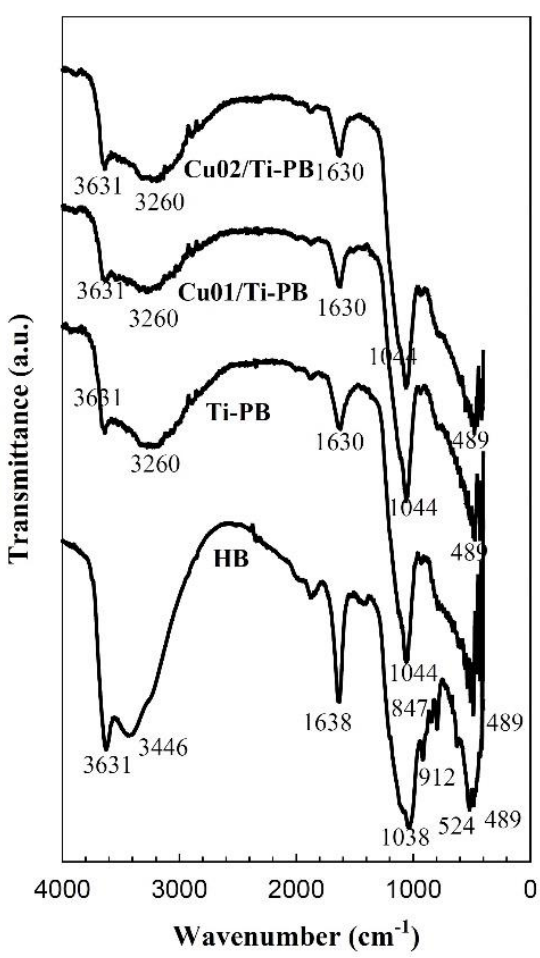

Figure 5. FTIR spectra of HB and pillared bentonites. with a change in the electric field near the $\mathrm{Si}$ groups due to the proximity of the more positively charged Ti pillars [33]. The intensities of the $\mathrm{Si}-\mathrm{O}$ bending and $\mathrm{Al}-\mathrm{O}$ stretching vibrations decreased and shifted to higher wavenumbers in the pillared bentonites. For the pillared samples, the interlayer water band at $3446 \mathrm{~cm}^{-1}$ shifted to lower wavenumbers with a simultaneous increase in the width showing an increase in the interlayer water content due to the replacement of inorganic cations with the metal pillars. Significant intensity decreases in the peaks at $3631 \mathrm{~cm}^{-1}$ and 400-1044 $\mathrm{cm}^{-1}$ were observed for all of the pillared materials. This result might be caused by linking of the Ti polyoxycations to $\mathrm{Al}-\mathrm{O}$ in the alumina octahedral sheet and silanol groups. The pillaring process replaces a large amount of interlayer cations that generally exist in the hydrated form, and this replacement increases the intensity of the $-\mathrm{OH}$ peaks in general. However calcination followed after pillaring caused a small decrease in the intensity of the bending vibrations at $1638 \mathrm{~cm}^{-1}$ compared with the room-dried bentonite and the vibration was shifted to $1636-1629 \mathrm{~cm}^{-1}$ by pillaring.

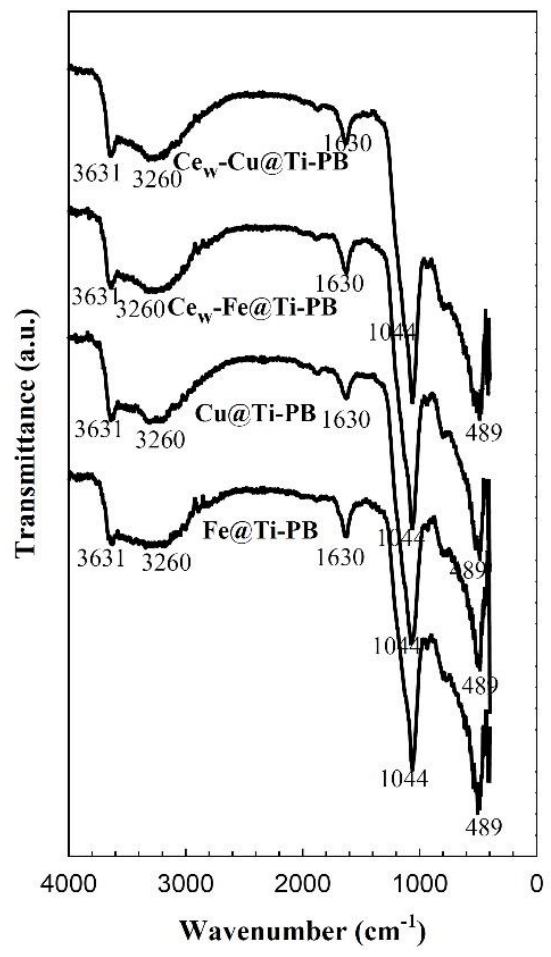


Figure 6 shows the infrared spectra of the pyridine adsorbed Ti-pillared bentonites subjected to pyridine desorption at room and elevated temperatures, respectively. The structure of anatase can be described in terms of chains of the $\mathrm{TiO}_{6}$ octahedra with all edge shared $\mathrm{O}-\mathrm{O}$ bonds [54]. The bulky and longer chain structure of the anatase phase resulted more surface functional oxygen groups. Because that the bands attributed to pyridine coordinately bound to Lewis sites $\left(1446 \mathrm{~cm}^{-1}\right)$ Lewis and Brønsted sites $\left(1491 \mathrm{~cm}^{-1}\right)$ and Brønsted sites $\left(1546 \mathrm{~cm}^{-1}\right)$ were observed for all of the Ti-PBs. The high intensity of the band around $1446 \mathrm{~cm}^{-1}$ in the Ti-PB was a very strong indicator of the high Lewis acidity caused by the high $\mathrm{TiO}_{2}$ content for all of the pillared samples. The Brønsted acid sites may arise from the hydroxyl groups attached to $\mathrm{Ti}$ and the structural hydroxyl groups in the pillared bentonite [55]. The copper bounded to titanium polyoxycation might result in an improvement in Brønsted acidity in the hydrothermal synthesis. The band corresponding to the Lewis bound pyridine of copper was more intense in the post incorporation than that of the other PB samples. The Lewis band dominated the other peaks for that sample and this was possibly due to the excessive amount of the copper incorporation consistent with EDS analysis (Figure 6, Table 2). The positive effects of iron and cerium yielded higher Brønsted acidity in the resulting PBs. The intensities of the bands corresponding to Lewis bounded pyridine decreased while the bands that correspond to strong interactions of pyridinefunctional groups were protected with an increase of pyridine desorption temperature. These results are in agreement with the results cited in the literature $[7,8]$.

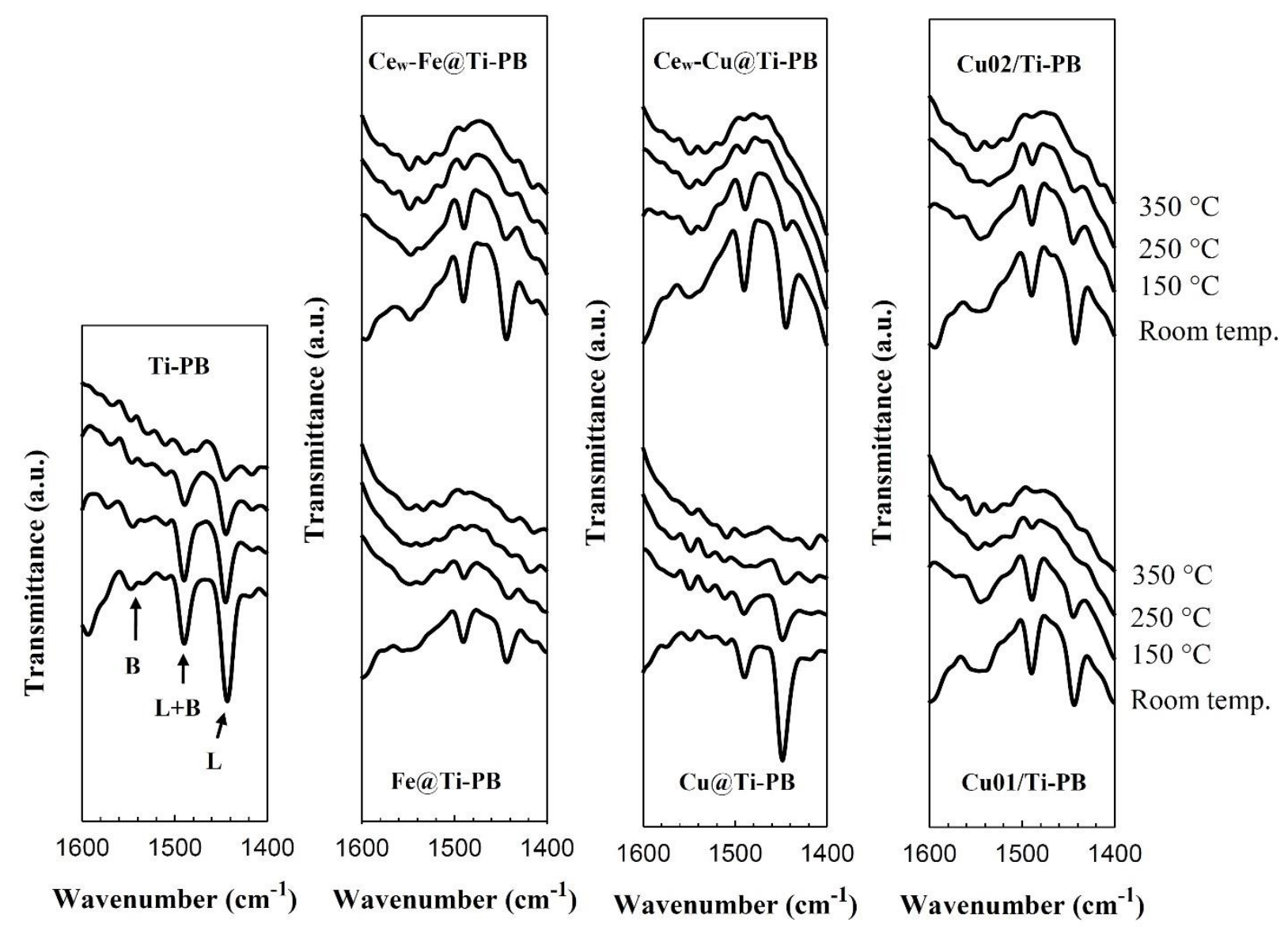

Figure 6. FTIR spectra of PBs and pyridine adsorbed and pyridine desorbed at room temperature $/ 150{ }^{\circ} \mathrm{C} / 250{ }^{\circ} \mathrm{C} / 350{ }^{\circ} \mathrm{C}$. 


\subsection{Photocatalytic wet peroxide oxidation of phenol}

Catalytic activities of the Ti-PB, Fe@Ti-PB, Cu@Ti-PB, Ce $e_{w}-F e @ T i-P B, C e_{w}-C u @ T i-P B$ samples were evaluated for photocatalytic wet peroxide oxidation of phenol and the phenol conversions are shown in Figure 7 and tabulated in Table 3. The Ti-PB showed a negligible amount of activity, reaching a phenol conversion of approximately $40 \%$ while $\mathrm{Fe}$ and $\mathrm{Ce}-\mathrm{Fe}$ containing samples showed around $50 \%$ conversion even at low reaction time. The conversion reached to approximately $90 \%$ in an hour and the completion of reaction was reached at 2 hours reaction time for these samples. The occurred high conversion values might be resulted due to high content of the Brønsted acidity. The other catalysts gave approximately $45 \%$ conversion values. Although Ti@ PB had a higher specific BET surface area and Cu@Ti-PB and $\mathrm{Ce}_{\mathrm{w}}-\mathrm{Cu} @ \mathrm{Ti}-\mathrm{PB}$ showed high $\mathrm{Cu}$ content, they showed lower activities. So the catalytic activities of the pillared bentonites in this reaction could depend more on the number and distribution of active sites than on the textural properties and the metal content of the pillared bentonites.

The variation of phenol conversions of Fe@Ti$\mathrm{PB}$ and $\mathrm{Ce}_{\mathrm{w}}-\mathrm{Cu} @ \mathrm{Ti}-\mathrm{PB}$ samples at different $\mathrm{pH}$ and different temperatures are given in Figure 8. The conversion of phenol via photocatalytic oxidation increased significantly by a rise of temperature. When the reaction temperature was $50{ }^{\circ} \mathrm{C}, \mathrm{Fe} @ \mathrm{Ti}-\mathrm{PB}$ catalyst gave approximately $90 \%$ conversion at 30 minutes and approximately $100 \%$ conversion at 60 minutes. An increase of $\mathrm{H}_{2} \mathrm{O}_{2}$ decomposition to $\mathrm{OH}^{-}$by an increase of temperature could accelerate the reaction $[8,41]$. However an increase of $\mathrm{pH}$ resulted in a decrease in the conversion value of Fe@Ti-PB, while around $30 \%$ increase was obtained for $\mathrm{Ce}_{\mathrm{w}}-\mathrm{Cu} @ \mathrm{Ti}-\mathrm{PB}$ after reaching the reaction time of 90 minutes. $\mathrm{pH}$ of a reaction mixture can affect electrostatic interactions between the reactant molecules and the catalyst surface [56]. The previous studies showed that acidic conditions were generally better for obtaining high phenol conversion. A decrease in phenol conversion by increasing $\mathrm{pH}$ value might be attributed to the tendency to produce a less reactive $\mathrm{OOH}^{*}$ (hydroperoxyl) radical except for $\mathrm{OH}^{*}$ radical at less acidic conditions. As the $\mathrm{pH}$ increases, catalyst deactivation can occur due to the formation of metal hydroxide complexes [57]. Because copper is less sensitive than iron to changes in a $\mathrm{pH}$ value, the copper containing catalysts are able to hold their activity in a wider $\mathrm{pH}$ range [58].

According to the reaction mechanism for the oxidation of phenol, the stages may be simplified as the following: (a) initial formation of hydroquinone and catechol upon hydroxylation of aromatic ring of phenol by hydrogen peroxide and then benzoquinone was formed; (b) aromatic ring cleavage, producing ring-opened products low weight organic acids, maleic acid, fumaric acid, oxalic acid, acetic acid and formic acid. Finally, the degradation of these compounds during reaction leads to $\mathrm{CO}_{2}$ and $\mathrm{H}_{2} \mathrm{O}$ formation $[59,60]$. The complete mineralisation (oxidation to $\mathrm{CO}_{2}+\mathrm{H}_{2} \mathrm{O}$ ) was not achieved in all of the samples (Table 3 ). The TOC conversion reached to $58 \%$ by Fe@Ti-PB at 4 hours and presence of cerium together with iron caused an increase in that value to $62 \%$. The value was reduced by half for the sample containing both cerium and copper. Aromatic compounds (hydroquinone, benzoquinone and catechol) and carboxylic acid species (formic, malic, fumaric acids) were observed as the reaction intermediates. The product distribution in phenol oxidation reaction are given in Figure 9 for Fe@Ti-PB. As expected, hydroquinone and catechol were less in an amount (near zero) in the interval of 90 and 240 minutes reaction range due to benzoquinone formation.For Fe@Ti-PB and $\mathrm{Ce}_{\mathrm{w}}$-Fe@Ti-PB at $\mathrm{pH}=3.7$ and $\mathrm{T}=30^{\circ} \mathrm{C}$, approximately $10 \mathrm{mg} / \mathrm{L}$ of benzoquinone was formed in the experimental time interval of 90-120 minutes, then started to decrease and totally disappeared because it 
converted to maleic acid and/or fumaric acid before the reaction completed. When maleic acid decreased, formic acid was increasing in all reaction media containing pillared samples. This also supported conversion of maleic acid to formic acid. Approximately $20 \mathrm{mg} / \mathrm{L}$ of each maleic acid and formic acid were observed at 240 minutes for Fe@Ti-PB and $\mathrm{Ce}_{\mathrm{w}}$-Fe@Ti-PB respectively. Increasing reaction temperature from $30{ }^{\circ} \mathrm{C}$ to $50{ }^{\circ} \mathrm{C}$ resulted in conversion of all benzoquinone to maleic acid and then formic and fumaric acids at the experimental time of 90 minutes for Fe@Ti-PB. Formic acid and fumaric acid amounts were obtained as less than $4 \mathrm{mgL}^{-1}$ at 240 minutes for Fe@ Ti-PB at pH value of 5 and Fe@Ti-PB at reaction temperature of $50{ }^{\circ} \mathrm{C}$. Decrease in amounts of formic acid and fumaric acid during reaction resulted in the conversion to $\mathrm{CO}_{2}$ and water. High conversion value to $\mathrm{CO}_{2}$ gave high TOC conversion value as $60 \%$ for Fe@Ti-PB at given reaction conditions (Table 3, Figure 9).

Studies involving pillared clays in phenol oxidation have been reported [10, 18, 37, 38]. Carriazo et al. [10] obtained $80 \%$ and $90 \%$ phenol conversions at 180 and 240 minutes respectively by using iron titanium pillared clay. $100 \%$ phenol conversion and $60 \%$ TOC conversion after 2 hours were obtained by using cerium and zirconium containing pillared clay catalyst in Mnasri Ghnimi and Frini-Srasra study [18]. In another study by Carriazo et al. [37], 90 $\%$ phenol conversion and $55 \%$ TOC conversion values after 1 hour of reaction were obtained by using Al-Ce-Fe-pillared clays. Similarly, Sanabria et al. [38] achieved $70 \%$ conversion of total phenolic compounds and TOC conversion $(50 \%)$ after five hours reaction time using $\mathrm{Al}$ $\mathrm{Ce}-\mathrm{Fe}$-pillared clay. It was shown that high phenol and TOC conversion values of iron impregnated Ti-PB in phenol oxidation were obtained when compared with the literature.

To investigate the stability of Fe@Ti-PB or $\mathrm{Cu} @ \mathrm{Ti}-\mathrm{PB}$ with respect to the metal leaching under severe acidic condition, concentration of dissolved iron or copper in the reaction solution was analysed and tabulated in Table 3 . The leaching of metals was observed at low values and the stability of iron was found six times higher than the copper in the catalyst structure. The iron leaching value was lower than those reported for $\mathrm{Fe}-\mathrm{Ti}$ - and $\mathrm{Al}-\mathrm{Fe}-\mathrm{Ce}-$ pillared clays $[10,37,38]$.

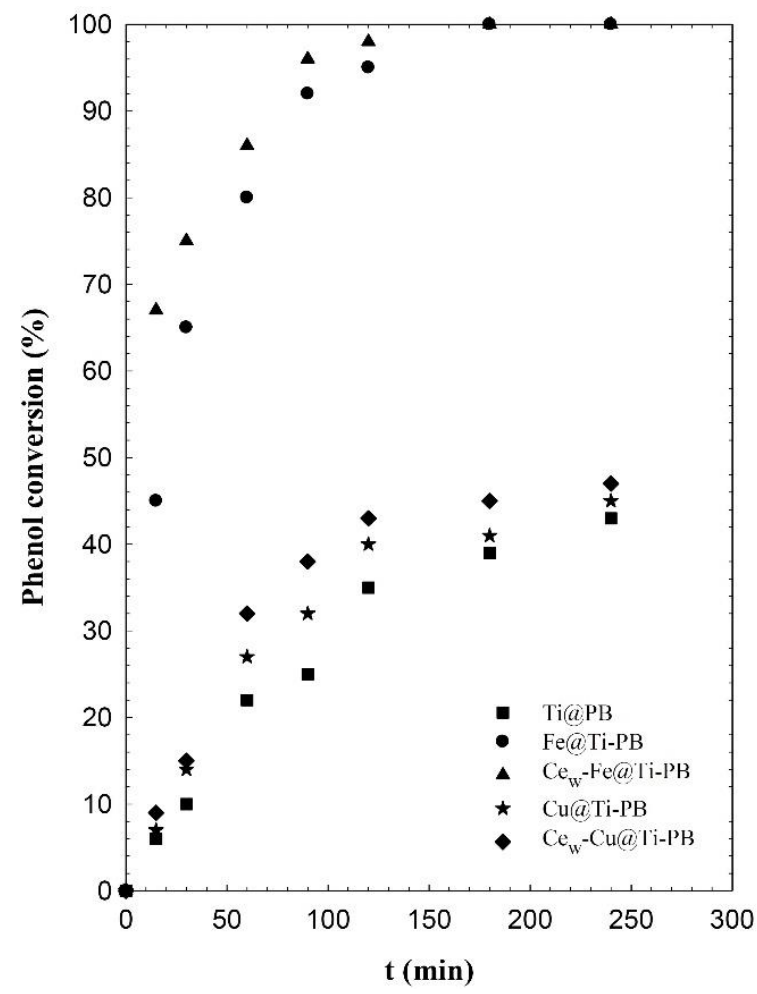

Figure 7. Phenol conversion of pillared bentonites at $\mathrm{T}=30$ ${ }^{\circ} \mathrm{C}$ and $\mathrm{pH}=3.7$ underatmospheric pressure with an initial phenol concentration $50 \mathrm{mg} / \mathrm{L}$. 

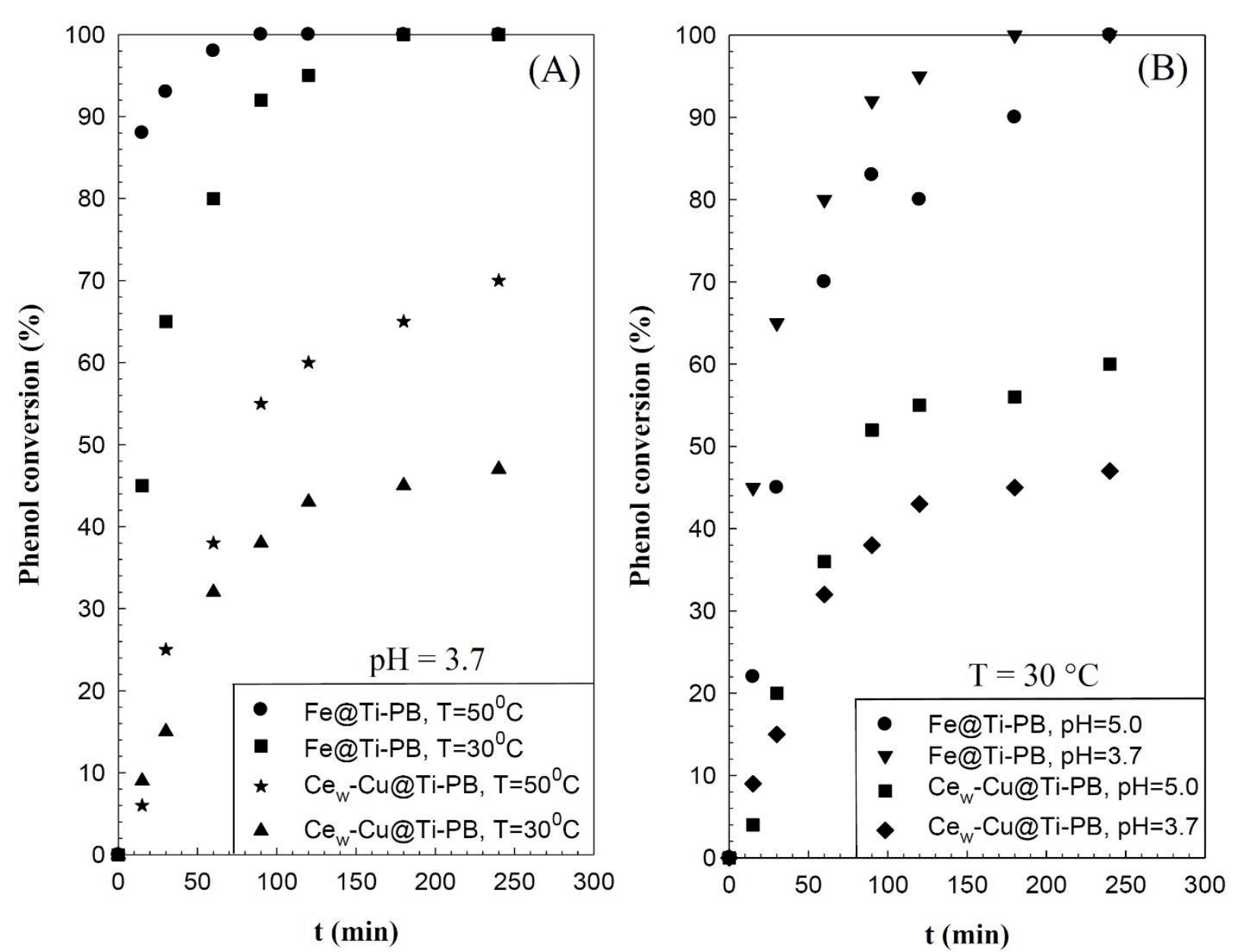

Figure 8. Phenol conversion of Fe@Ti-PB and $\mathrm{Ce}_{w}-\mathrm{Cu} @ \mathrm{Ti}-\mathrm{PB}$ at atmospheric pressure with $50 \mathrm{mg} / \mathrm{L}$ phenol A) at different temperatures, $\mathrm{pH}=3.7 \mathrm{~B}$ ) at different $\mathrm{pH}$ values $\mathrm{T}=30^{\circ} \mathrm{C}$. 

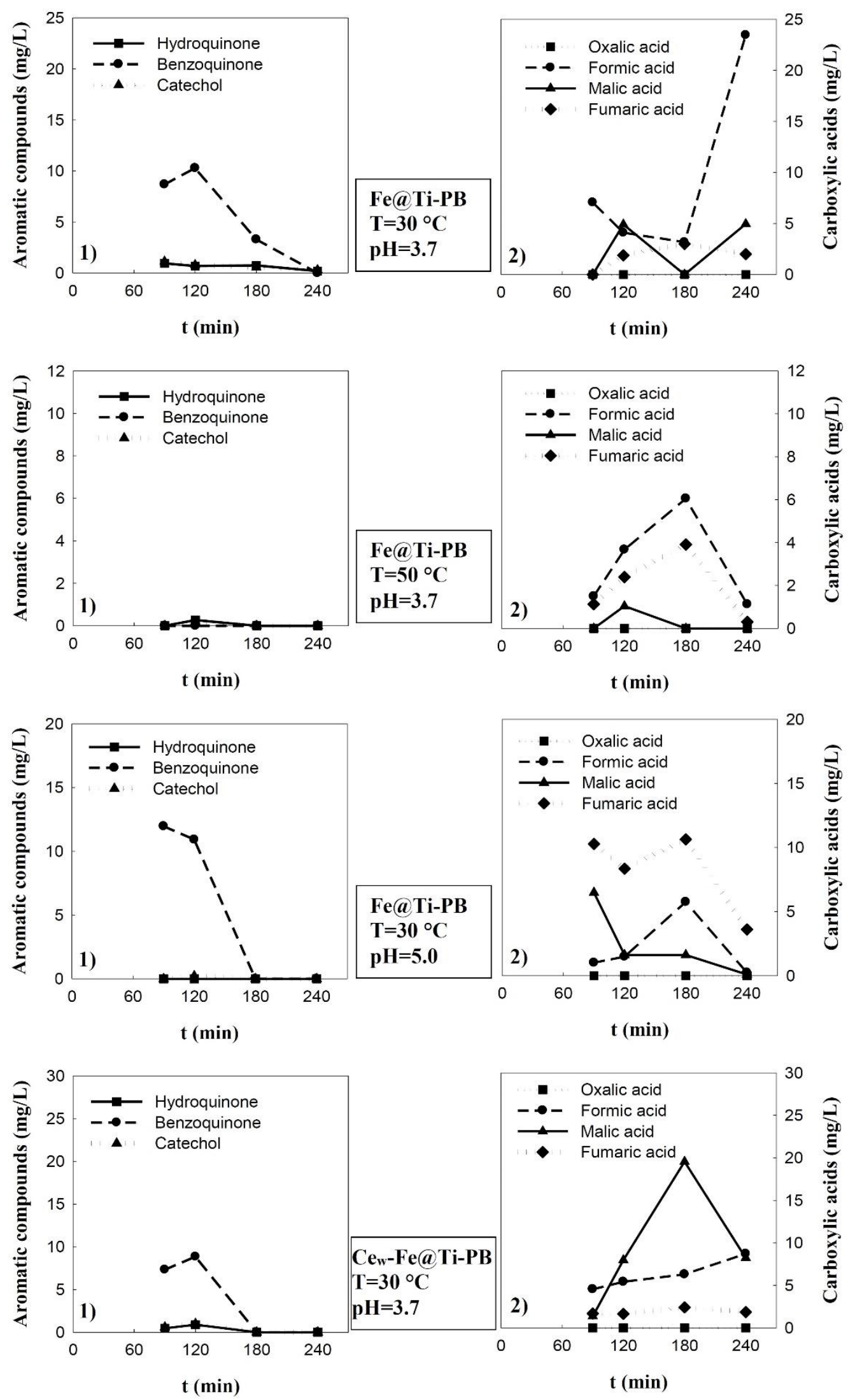

Figure 9. Effects of temperature and $\mathrm{pH}$ on the product distribution. 1) Aromatic compounds formations 2) Carboxylic acids formations. 
Table 3. Phenol and TOC conversion percentages, metal contents in reaction solution at 240 minutes for pillared samples.

\begin{tabular}{llll}
\hline Samples & $\begin{array}{l}\text { Phenol } \\
\text { conversion }(\%)\end{array}$ & $\begin{array}{l}\text { TOC } \\
\text { conversion }(\%)\end{array}$ & $\begin{array}{l}\text { Fe or Cu concentrations in reaction } \\
\text { solution }(\mathrm{mg} / \mathrm{L})\end{array}$ \\
\hline $\mathrm{Ti}-\mathrm{PB}$ & 43 & - & - \\
$\mathrm{Fe} @ \mathrm{Ti}-\mathrm{PB}$ & 100 & 58 & $0.87 \pm 0.02$ \\
$\mathrm{Fe} @ \mathrm{Ti}-\mathrm{PB}, \mathrm{T}=50{ }^{\circ} \mathrm{C}$ & 100 & 60 & $0.39 \pm 0.02$ \\
$\mathrm{Fe} @ \mathrm{Ti}-\mathrm{PB}, \mathrm{pH}=5.0$ & 100 & 60 & $0.15 \pm 0.02$ \\
$\mathrm{Ce}_{\mathrm{w}}-\mathrm{Fe} @ \mathrm{Ti}-\mathrm{PB}$ & 100 & 62 & $0.45 \pm 0.02$ \\
$\mathrm{Ce}_{\mathrm{w}}-\mathrm{Cu} @ \mathrm{Ti}-\mathrm{PB}, \mathrm{T}=50^{\circ} \mathrm{C}$ & 70 & 30 & 2.880 .02 \\
\hline
\end{tabular}

\section{CONCLUSION}

Different combinations of copper, iron, cerium were successfully inserted into Ti-PB structure by the metal impregnation method. The $\mathrm{d}_{001}$ values were found out so high however the reflections had low intensity due to the presence of delaminated regions in the pillared structure. The samples with a significantly high specific BET surface area and the microporous structure were synthesised. The different sized pores in the micropore region could be resulted with the interpillar spacing and the pores within the Tipillars. The sharp narrow peaks were obtained in the mesopore region. The average micropore dimensions obtained by the DA method were almost four times higher than those obtained by the HK method. The peaks corresponding to the Brønsted, Lewis and Brønsted+Lewis acidity were observed for the Ti-PB structure. The presence of iron and cerium increased the Brønsted acidity content and copper increased the Lewis acidity in general.

Ti-PB, cerium containing and iron or copper impregnated Ti-PBs were found active in the photocatalytic wet peroxide oxidation of phenol. $\mathrm{Ce}_{\mathrm{w}}-\mathrm{Fe} @ \mathrm{Ti}-\mathrm{PB}$ resulted in approximately $90 \%$ phenol conversion at an hour under the experimental conditions of $\mathrm{T}=30^{\circ} \mathrm{C}, \mathrm{pH} 3.7$ and $\mathrm{m}_{\text {cat }}=5 \mathrm{~g} / \mathrm{L}$. The increase of the reaction temperature exhibited an increase in the phenol conversion values. The reaction intermediates were hydroquinone, benzoquinone, catechol, formic, malic and fumaric acids.

\section{Acknowledgement}

The author wish to thank the financial support from the Scientific Research Project Department of Gazi University for supporting project code
BAP 06/2009-49. This work was a part of project code BAP 06/2009-49.

\section{REFERENCES}

[1] Gil A., Korili S.A., Trujillano R. and Vicente M.A., A review on characterization of pillared clays by specific techniques, Appl. Clay Sci., 53 (2011) 97-105.

[2] Bergaya F., Aouad A., Mandalia T., Pillared clays and clay minerals, In: Bergaya F., Theng B.K.G., Lagaly G. (Eds.). Development in Clay Science: Handbook of Clay Science. vol. 1, 2nd ed., Amsterdam: Elsevier, 2011; pp 393421.

[3] Vicente M.A., Gil A., Bergaya F., Pillared clays and clay minerals, In: Bergaya F., Lagaly G. (Eds.), Development in Clay Science: Handbook of Clay Science, Part A: Fundamentals, vol. 5, 2nd ed., Amsterdam: Elsevier, 2013; pp 523-557.

[4] Fechete I., Wang Y. and Vedrine J.C., The past, present and future of heterogeneous catalysis, Catal. Today, 189 (2012) 2- 27.

[5] Centi G. and Perathoner S., Catalysis by layered materials: a review, Microporous Mesoporous. Mater., 107 (2008) 3-15.

[6] Turgut Basoglu F. and Balci S., Catalytic properties and activity of copper and silver containing Al-pillared layered bentonite for CO oxidation, J. Molecular Struct., 1106 (2016) 382-389.

[7] Turgut Basoglu F., Effect of the titanium source on the structural properties and acidity of Ti-pillared bentonite, Chem. Pap., 70-7 (2016) 933-945.

[8] Tomul F., Turgut Basoglu F. and Canbay H., Determination of adsorptive and catalytic properties of copper, silver and iron containing titanium-pillared 
bentonite for the removal bisphenol A from aqueous solution, Appl. Surf. Sci., 360 Part B (2016) 579-593.

[9] Bineesh K.V., Kim D., Kim M. and Park D., Selective catalytic oxidation of $\mathrm{H}_{2} \mathrm{~S}$ over $\mathrm{V}_{2} \mathrm{O}_{5}$ supported on $\mathrm{TiO}_{2}$-pillared clay catalysts in the presence of water and ammonia, Appl. Clay Sci., 53 (2011) 204211.

[10] Carriazo J.G., Moreno-Forero M., Molina R.A. and Moreno S., Incorporation of titanium and titanium iron species inside a smectite type mineral for photocatalysis, Appl. Clay Sci., 50 (2010) 401-408.

[11] Chen K., Li J., Li J., Zhang Y. and Wang W., Synthesis and Characterization of $\mathrm{TiO}_{2}$ montmorillonites doped with vanadium and/or carbon and their application for the photodegredation of sulphorbodamine B under UV-vis irradiation, Colloids Surf. A, 360 (2010) 47-56.

[12] Chmielarz L., Piwowarska Z., Kustrowski P., Wegrzyn A., Gil B., Kowalczyk A., Dudek B., Dziembaj R. and Michalik M., Comparison study of titania pillared interlayered clays and porous clay heterostructures modified with copper and iron as catalysts of the DeNOx process, Appl. Clay Sci., 53 (2011) 164-173.

[13] Lu G., Li X., Qu Z., Zhao Q., Zhao I. and Chen G., Copper ion exchanged Tipillared clays for selective catalytic reduction of NO by propylene, Chem. Eng. J., 168 (2011) 1128-1133.

[14] Zhang J., Zhang S., Cai W. and Zhong Q., The characterization of CrCe-doped on $\mathrm{TiO}_{2}$-pillared clay nanocomposites for $\mathrm{NO}$ oxidation and the promotion effect of $\mathrm{CeO}_{x}$, Appl. Surf. Sci., 268 (2013) 535540.

[15] Busca G., Berardinelli S., Resini C. and Arrighi, L., Technologies for the removal of phenol from fluid streams: A short review of recent developments, J. Hazard. Mater., 160 (2008) 265-288.

[16] Ye W., Zhao B., Gao H., Huang J. and Zhang X., Preparation of highly efficient and stable $\mathrm{Fe}, \mathrm{Zn}$, Al-pillared montmorillonite as heteregeneous catalyst for catalytic wet peroxide oxidation of Orange II, J. Porous Mater., 23 (2016) 301-310.

[17] Galeano L-A., Vicente M.A. and Gil A., Catalytic degradation of organic pollutants in aqueous streams by mixed $\mathrm{Al} / \mathrm{M}$-pillared clays $(\mathrm{M}=\mathrm{Fe}, \mathrm{Cu}, \mathrm{Mn})$, Catal. Rev. Sci. Eng., 56 (2014) 239-287.

[18] Mnasri-Ghnimi S. and Frini-Srasra N., Catalytic wet peroxide oxidation of phenol over Ce-Zr-modified clays: Effect of the pillaring method, Korean J. Chem. Eng., 32-1 (2015) 68-73.

[19] Yan Y., Jiang S., Zhang H. and Zhang X., Preparation of novel Fe-ZSM-5 zeolite membrane catalysts for catalytic wet peroxide oxidation of phenol in a membrane reactor, Chem. Eng. J., 259 (2015) 243-251.

[20] Luca C., Massa P., Fenoglio R. and Cabello F.M., Improved $\mathrm{Fe}_{2} \mathrm{O}_{3} / \mathrm{Al}_{2} \mathrm{O}_{3}$ as heteregeneous Fenton catalysts for the oxidation of phenol solutions in a continuous reactor, J. Chem. Technol. Biotechnol., 89 (2014) 1121-1128.

[21] Martinez F., Pariente M.I., Botas J.A., Melero J.A. and Rubalcaba A., Influence of preoxidizing treatments on the preparation of iron-containing activated carbons for catalytic wet peroxide oxidation of phenol, J. Chem. Technol. Biotechnol., 87 (2012) 880-886.

[22] Satishkumar G., Landau M.V., Buzaglo T., Frimet L., Ferentz M., Vidruk R., Wagner F., Gal Y. and Herskowitz M., $\mathrm{Fe} / \mathrm{SiO}_{2}$ heteregeneous Fenton catalyst for continuous catalytic wet peroxide oxidation prepared in situ by grafting of iron released from $\mathrm{LaFeO}_{3}$, Appl. Catal. B Environ., 138-139 (2013) 276-284.

[23] Zhong X., Barbier J., Duprez D., Zhang H. and Royer S., Modulating the copper oxide morphology and accessibility by using micro-/mesoporous SBA-15 structures as host support: effect on the activity for the CWPO of phenol reaction, Appl. Catal. B Environ., 121-122 (2012) 123-134.

[24] Dougna A.A., Gombert B., Kodom T., Djaneye-Boundjou G., Boukari S.O.B., Vel Leitner N.K. and Bawa L.M., Photocatalytic removal of phenol using titanium dioxide deposited on different substrates: Effect of inorganic oxidants, J. Photochem. Photobio. A Chem., 305 (2015) 67-77.

[25] Khraisheh M., Wu L., Al-Muhtaseb A.H., Albadarin A.B. and Walker G.M., Phenol degradation by powdered metal ion 
modified titanium dioxide photocatalysts, Chem. Eng. J., 213 (2012) 125-134.

[26] Lopes R.J.G., Perdigoto M.L.N. and Quinta-Ferreira R.M., Tailored investigation and characterization of heteregeneous $\{\mathrm{Mn}, \mathrm{Cu}\} / \mathrm{TiO}_{2}$ catalysts embedded within a ceria-based framework for the wet peroxide oxidation of hazardous pollutants, Appl. Catal. B Environ., 117-118 (2012) 292-301.

[27] Menesi J., Körösi L., Bazso E., Zöllmer V., Richardt A. and Dekany I., Photocatalytic oxidation of organic pollutants on titania-clay composites, Chemosphere, 70 (2008) 538-542.

[28] Turki A., Guillard C., Dappozze F., Ksibi Z., Berhault G. and Kochkar H., Phenol photocatalytic degradation over anisotropic $\mathrm{TiO}_{2}$ nanomaterials: Kinetic study, adsorption isotherms and formal mechanisms, Appl. Catal. B Environ., 163 (2015) 404-414.

[29] Li Z., Sheng J., Zhang Y., Li X. and Xu $\mathrm{Y}$., Role of $\mathrm{CeO}_{2}$ as oxygen promoter in the accelerated photocatalytic degradation of phenol over rutile $\mathrm{TiO}_{2}$, Appl. Catal. B Environ., 166-167 (2015) 313-319.

[30] Mnasri-Ghnimi S. and Frini-Srasra N., Effect of $\mathrm{Al}$ and $\mathrm{Ce}$ on $\mathrm{Zr}$-pillared bentonite and their performance in catalytic oxidation of phenol, Russian J. Phys. Chem. A, 90-9 (2016) 1766-1773.

[31] Timofeeva M.N., Khankhasaeva S.Ts., Talsi E P., Panchenko V.N., Golovin A.V., Dashinamzhilova E.Ts. and Tsybulya S.V., The effect of $\mathrm{Fe} / \mathrm{Cu}$ ratio in the synthesis of mixed $\mathrm{Fe}, \mathrm{Cu}, \mathrm{Al}$-clays used as catalysts in phenol peroxide oxidation, Appl. Catal. B Environ., 90 (2009) 618-627.

[32] Tomul F., The effect of ultrasonic treatment on iron-chromium pillared bentonite synthesis and catalytic wet peroxide oxidation of phenol, Appl. Clay Sci., 120 (2016) 121-134.

[33] Tomul F., Influence of synthesis conditions on the physicochemical properties and catalytic activity of $\mathrm{Fe} / \mathrm{Cr}$ pillared bentonites, J. Nanomater., (2012) DOI:10.1155/2012/237853.

[34] Tomul F., Effect of ultrasound on the structural and textural properties of copper-impregnated cerium-modified zirconium-pillared bentonite, Appl. Surf. Sci., 258 (2011) 1836-1848.
[35] Olaya A., Blanco G., Bernal S., Moreno S. and Molina R., Synthesis of pillared clays with $\mathrm{Al}-\mathrm{Fe}$ and $\mathrm{Al}-\mathrm{Fe}-\mathrm{Ce}$ starting from concentrated suspensions of clay using microwaves or ultrasound, and their catalytic activity in the phenol oxidation reaction, Appl. Catal. B Environ., 93 (2009) 56-65.

[36] Platon N., Siminiceanu I., Nistor I.D., Silion M., Jinescu J., Harrouna M. and Azzouz A., Catalytic wet oxidation of phenol with hydrogen peroxide over modified clay minerals, Rev. Chim., 6412 (2013) 1459-1464.

[37] Carriazo J. G., Molina R. and Moreno S., A study on $\mathrm{Al}$ and $\mathrm{Al}-\mathrm{Ce}-\mathrm{Fe}$ pillaring species and their catalytic potential as they are supported on a bentonite, Appl. Catal. A Gen., 334 (2008) 168-172.

[38] Sanabria N.R., Peralta Y.M., Montanez M.K., Rodriguez-Valencia N., Molina R. and Moreno S., Catalytic oxidation with $\mathrm{Al}-\mathrm{Ce}-\mathrm{Fe}-\mathrm{PILC}$ as a post-treatment system for coffee wet processing wastewater, Water Sci. Tech., 66-8 (2012) 1663-1668.

[39] Yang S., Liang G., Gu A. and Mao H., Synthesis of mesoporous ironincorporated silica-pillared clay and catalytic performance for phenol hydroxylation, Appl. Surf. Sci., 285 (2013) 721-726.

[40] Ooka C., Yoshida H., Suzuki K. and Hattori T., Highly hydrophobic $\mathrm{TiO}_{2}$ pillared clay for photocatalytic degradation of organic compounds in water, Microporous Mesoporous Mater., 67 (2004) 143-150.

[41] Herney-Ramirez J., Vicente M.A. and Madeira L.M., Heteregeneous photoFenton oxidation with pillared clay-based catalysts for wastewater treatment:A review, Appl. Catal. B Environ., 98 (2010) 10-26.

[42] Garrido-Ramirez E.G., Theng B.K.G. and Mora M.L., Clays and oxide minerals as catalysts and nanocatalysts in Fenton-like reactions-A review, Appl. Clay Sci., 47 (2010) 182-192.

[43] Khankhasaeva S. Ts., Dashinamzhilova E. Ts. and Dambueva D. V., Oxidative degradation of sulfanilamide catalyzed by $\mathrm{Fe} / \mathrm{Cu} / \mathrm{Al}$-pillared clays, Appl. Clay Sci., 146 (2017) 92-99. 
[44] Campo E.M., Romero R., Roa G., PeraltaReyes E., Espino-Valenvia J. and Natividad R., Photo-Fenton oxidation of phenolic compounds catalyzed by ironPILC, Fuel, 138 (2014) 149-155.

[45] Turgut Basoglu F. and Balci S., Micromesopore analysis of $\mathrm{Cu}^{2+}$ and $\mathrm{Ag}^{+}$ containing Al-pillared bentonite, Appl. Clay Sci., 50 (2010) 73-80.

[46] Arfoui J., Boudali L.K. and Ghorbel A., Vanadia-doped titanium-pillared clay: Preparation, characterization and reactivity in the epoxidation of allylic alcohol (E)-2-hexen-1-ol., Catal. Commun., 7 (2006) 86-90.

[47] Yang R.T., Chen J.P., Kikkinides E.S. and Cheng L.S., Pillared clays as superior catalysts for selective catalytic reduction of $\mathrm{NO}$ with $\mathrm{NH}_{3}$, Ind. Eng. Chem. Res., 31 (1992) 1440-1445.

[48] Chmielarz L., Piowowarska Z., Kustrowski P., Wegrzyn A., Gil B., Kowalczyk A., Dziembaj B. and Michalik M., Comparison study of titania pillared interlayered clays and porous clay heterostructures modified with copper and iron as catalysts of the DeNOx process, Appl. Clay Sci., 53 (2011) 164-173.

[49] Lowell S., Shields J.E., Thomas M.A., Thommes M., Characterization of Porous Solids and Powders: Surface Area, Pore Size and Density, Kluwer Academic Publishers, 2004; pp 213-228.

[50] Rauquerol F., Rauquerol J., Sing K., Adsorption by powders and porous solids, London: Academic Press, 1999; pp 165234.

[51] Olmez-Hanci T. and Arslan-Alaton I., Comparison of sulfate and hydroxyl radical based advanced oxidation of phenol, Chem. Eng. J., 224 (2013) 10-16.

[52] Koyuncu F., Organic acid composition of native black mulberry fruit, Chem. Nat. Comp., 40 (2004) 367-369.

[53] Anirudhan T.S., Bringle C.D. and Rijith S., Removal of uranium(VI) from aqueous solutions and nuclear industry effluents using humic acdi-immobilized zirconiumpillared clay, J. Environ. Radioact., 101 (2010) 267-276.

[54] Diebold U., The surface science of titanium dioxide, Surf. Sci. Rep., 48 (2003) 53-229.

[55] Farfan-Torres E.M., Sham E. and Grange P., Pillared clays: Preparation and characterization of zirconium pillared montmorillonite, Catal. Today, 15 (1992) 515.

[56] Yu L., Wang C., Ren X. and Sun H., Catalytic oxidative degredation of bisphenol A using an ultrasonic assisted tourmaline-based system: influence factors and mechanism study, Chem. Eng. J., 252 (2014) 346-354.

[57] Khanikar N. and Bhattacharyya K.G., $\mathrm{Cu}$ (II)-kaolinite and $\mathrm{Cu}$ (II)montmorillonite as catalysts for wet oxidative degredation of 2-chlorophenol, 4-chlorophenol and 2,4-dichlorophenol, Chem. Eng. J., 233 (2013) 88-97.

[58] Yip A.C., Lam F.L. and Hu X., Chemical vapor deposited copper on acid activated bentonite clay as an applicable heteregeneous catalyst for the photoFenton-like oxidation of textile organic pollutants, Ind. Eng. Chem. Res., 44 (2005) 7983-7990.

[59] Rokhina E.V. and Virkutyte J., Environmental application of catalytic processes: heterogeneous liquid phase oxidation of phenol with hydrogen peroxide, Critical Rev. Environ. Sci. Tech., 41 (2011) 125-167.

[60] Zhong X., Barbier Jr. J., Duprez D., Zhang $\mathrm{H}$. and Royer S., Modulating the copper oxide morphology and accessibility by using micro-/mesoporous SBA-15 structures as host support: Effect on the activity for the CWPO of phenol reaction, Appl. Catal. B: Environ., 121-122 (2012) 123- 134. 